British Journal of Economics, Management \& Trade
7(4): 288-295, 2015, Article no.BJEMT.2015.091
ISSN: 2278-098X
SCIENCEDOMAIN international
WwW.Sciencedomain.org

\title{
Is There A Casual Relationship Between Lending Interest Rate and Credit Availability to Households in Namibia?
}

\author{
Sakaria A. Kalumbu ${ }^{1}$ and Jacob M. Nyambe ${ }^{1^{*}}$ \\ ${ }^{1}$ Department of Economics, University of Namibia, P/Bag 13301, Windhoek, Windhoek, \\ Namibia. \\ Author's contributions \\ This work was carried out in collaboration between both authors. \\ Article Information \\ DOI: 10.9734/BJEMT/2015/13982 \\ Editor(s): \\ (1) Polona Tominc, Department of Quantitative Economic Analysis, University of Maribor, Slovenia. \\ (1) Anonymous, France. \\ (2) Anonymous, Turkey. \\ (3) Anonymous, Nigeria. \\ Complete Peer review History: http://www.sciencedomain.org/review-history.php?iid=981\&id=20\&aid=8993
}

Original Research Article
Received $12^{\text {th }}$ September 2014

Accepted $31^{\text {st }}$ December 2014

Published 27 ${ }^{\text {th }}$ April 2015

\section{ABSTRACT}

This study purposed to answer the question of whether or not there exist a causal relationship between the lending interest rate and credit volume available to households in Namibia. Analytical methods of unit root, Johansen cointegration, Granger-causality and the impulse response function were all used for estimation. The study period is the year 2000 to 2012 using panel data. Lending rate and credit stock available proved to be significant but with an inexistence of a long-run relationship between them. There is a one directional causal relationship between lending interest rate and credit available to households in Namibia which runs from credit availability to lending interest rate. Having also found a positive relationship between credit availability and lending interest rate in Namibia, lending rate should be sustained at a slightly higher level in order for the economy to keep prices stable.

Keywords: Unit root test; lending rate; and consumption spending. 


\section{INTRODUCTION}

Lending rate is one of the several interest rates that are used in the financial service sector. It is also the rate of interest that commercial banks consider when lending money to the general public. Namibia is not an exception to the idea that borrowing can spur consumption levels of households. As a result of uncertainty from the side of a consumer, accessible and affordable credit often serves well in smoothening the borrower's consumption patterns and daily obligations. Usually, households insulate their consumption in two ways, namely insurance and credit or financial markets [1]. On the one end, insurance is like savings in a way in that consumers put away certain amounts for precautionary purposes. Borrowing, on the other end, occurs when consumers draw from the financial market to support their living standards. In most cases, borrowing happens because of consumers' inability to save for the future needs. Borrowing in the financial services sector takes place in two ways, namely consumers can borrow from the informal financial sector, which includes the money lenders, families, friends, and also from the formal financial sector in which the commercial banks are found. The focus of this study is on the formal financial sector. In Namibia, commercial banks borrow from the central bank at a given repo rate and lend funds out at a specified lending rate.

Since the lending rate is one of the interest rates in the financial market, it reflects how responsive household's demand for credit is to a change in interest rate. This makes it one of the important and potential channels that can reflect the impact of interest rate on the availability of credit to households [2]. The popular opinion is that the lending interest rate is negatively related to consumption which brings about some reduction in the demand component [2,3]. Generally, households are assumed to consume a constant portion of the present value of their lifetime income and save while they are working in order to finance their consumption after retirement [3].

A study was done on the Namibian economy, focusing on deposit rates and lending rate, excluding credit availability [4]. Most studies done similar to this one mostly focus deposit rate, with respect to other economies $[5,6]$. Despite all these studies, there is still a need for empirical studies especially in demystifying the casual relationship between lending interest rate and credit availability to households in Namibia. Thus this study aims to fill that gap.

\section{LITERATURE REVIEW}

\subsection{Theoretical Literature}

There are several theories that link interest rate and credit availability. One such fundamental ones that touch on the interest rate and credit availability is the Life Cycle Model. The Life Cycle Model is from Modigliani's school of thought [7]. This theory states that income changes systematically over the phases of the household's life-cycle. Under the Life Cycle Model, credit could be used to smooth consumption, so as to increase household utility [8]. It is also assumed that credit under this theory serves to smooth consumption, to impose discipline on households and also to serve for uncertainty. With a diminishing marginal utility of consumption, households' expecting high future income might borrow in order to move some of their consumption forward [8]. In addition, the proportional lifetime income spent by households on consumption in any given period depends on the interest rate, the age and a multi-period utility function [9].

The elderly are likely to have a bigger portion of safety assets and savings. This shows that their consumption level is suppressed by a reduction in interest payments when the rate of interest goes down. As a rule, interest rate is as a remuneration to capital and but also a cost to borrowing under the Life Cycle Model.

Households are assumed to use their whole life span planning for their consumption and are assumed to smooth their consumption through savings. Under this model, it savings could be used as a mechanism of transferring purchasing power from one period to another [10]. That means that if a consumer saves today s/he can use up that savings for consumption in the next period. In other words, the amount of money forgone today is used up in consumption in the following period. The Life Cycle Model further assumes that income is usually low in the early periods of life compared to the later years in life. That happens because in the early periods most consumers are young and they do not work but depend on those around them for financial assistance. As young consumers grow older, they complete their education, find jobs and start earning their own income which is relatively 
higher compared to the one they used to have when they were young.

Therefore, under the Life Cycle Model, current consumption and saving decisions are parts of the households' lifetime plans in order for them to maintain constant levels of consumption even after retirement. While households tend to save throughout their working lives, they tend to consume less than their incomes. During their working period, they accumulate enough savings to enable them to sustain the same level of consumption during retirement [10]. As stated earlier, when households retire their income falls significantly. For them to maintain the level of consumption they had during their working period, households use up their past savings. The later shows that consumption is not only dependent on current income, but also on the level of wealth that the consumer holds. That can be represented by the following function:

$$
C_{t}=\mathrm{a} w_{t+1}+\mathrm{bY} Y_{t}+\mathrm{b} 2 Y_{t}^{e}+U_{t} \ldots \ldots \ldots \ldots \ldots(1)
$$

Where $C_{t}$ is current real consumption spending in period $t, w_{t+1}$ is total real wealth or savings which households have accumulated up to the end of period $t-1 . Y_{t}$ is the total current real income of all households in period $\mathrm{t}, Y_{t}^{e}$ is what household estimate to be their annual real income from period $t+1$ upwards, $U_{t}$ is the random error term.

In the last part of the working life, income tends to reach its peak. Income also falls as consumers reach their retirements [10]. It was from that point of view that [10] mentioned that consumers are not all better off in life and those who wish to smooth their consumption are likely to borrow in their early low income periods, build up their wealth, repay those funds in the high income periods and spend the accrued savings during retirement when income is dropping monotonically. It is due to the life process that the model engenders that it earned itself the name 'Life-Cycle Model'.

It is further assumed that there was a budget constraint that links consumption at various stages during the lifetime of a consumer [10]. The slope of that budget constraint also determines the tradeoff between consumption in period $t$ and the consumption in period $t+1$. The slope is given as:

$$
-(1+r)
$$

Where $r$ is the real interest rate at which consumers borrow.
The position of the budget constraint depends on the present value of lifetime earnings or wealth [10], which is given as:

$$
\Omega_{0}=A_{0}+\sum_{t=0}^{T} \frac{Y t}{(1+r)^{t}}
$$

where $\Omega_{0}$ is the stock of wealth, both human and non-human wealth at time zero, $A_{0}$ is the value of current financial and physical assets, $Y_{t}$ for $t=$ $0,1,2, . . ; \mathrm{T}$ is the expected stream of real labor income over time and $r$ is the real interest rate. According to [10], early empirical tests were conducted aimed at explaining if wealth and interest rate explain consumption better that current disposable income, but measuring wealth was difficult and made testing the Life-Cycle Model difficult. Despite all the hurdles the Life Cycle Model is one of the theories that link interest rates to credit through consumption.

\subsection{Emperical Literature}

There are several studies done on credit availability and interest rate. Ina study on credit accessibility in France and America [8], it was discovered that interest rate reduces the borrower's purchasing power over time. Borrowing allows households to move their consumption forward; however, total consumption will fall by the amount of interest rate paid back to the borrowed funds and this interest payment is withdrawn from future consumption. Unlike businesses where debts create stream of income out of which the loan is repaid, households borrow mostly for pure consumption which turns out to become a liability [8]. This shows that the interest rate has a negative impact on credit.

The same view was also supported in the study of the casual relationship between interest rate and inflation in Turkey [11]. In that study, interest rate influenced the demand side of the economy. The demand side of the economy is defined by the equilibrium in the money market, as well as one in the product market. So, an increase of interest rate in the money market leads to an increase in the opportunity cost of holding money. This has a negative impact on money demand and leads to a fall in demand for money [11]. This reduction in money demand creates excess supply of credit. It was further pointed out that an increase in interest rate increases the cost of borrowing, which in turn reduces aggregate demand through the fall in investment demand [11]. Thus, interest rate has a negative 
impact on credit availability, leading to an increase in aggregate demand.

High interest rate makes it expensive for households to borrow [12]. On consumption, the increment in consumption level is explained by credit availability [13-15]. Limited excess to credit limits households from borrowing, which constrains households from smoothing their consumption and other obligations. In a study on the relationship between lending interest rate and deposit rate in Namibia, it indicates that interest rate is a cost to borrowing by households whose repayments benefits lenders [4].

Credit availability and credit volume are important factors for economic growith in the sense that the supply of credit to households can significantly affect real economic activity [16-18]. Similarly, in a study on the relationship between default risk and interest rate in the US economy between 1982 and 2008, the importance of credit availability to economic growth is highlighted [19]. It was found that if interest rate changes unexpectedly, its impact on credit availability will help explain how assets and liabilities line up. This shows that interest rate and credit availability play an important role in policy instruments and economic growth.

Therefore, it shows that the lending interest rate has a negative impact on credit volume and availability to households. An increase in the lending rate leads to a fall in credit availability thereby reducing borrowing by households.

\section{MATERIALS AND METHODS}

\subsection{Model Specification and Econometric Framework}

This study makes use of the Vector autoregressive (VAR) model. In the VAR model, each variable is explained by its own lagged variable [20]. The model adopts the following two dimensional VAR equations:

$$
\begin{aligned}
& L I R_{t}=\alpha_{11} L I R_{t-1}+\alpha_{12} C H_{t-1}+\varepsilon 1_{t} \ldots \ldots \ldots(4) \\
& C H_{t}=\alpha_{2} L I R_{t-1}+\alpha_{2} C H_{t-1}+\varepsilon 2_{t} \ldots \ldots \ldots(5)
\end{aligned}
$$

where $L_{I R}$ represents lending interest rate with respect to time $\mathrm{t}, \mathrm{CH}_{\mathrm{t}}$ represents credit to households with respect to time $\mathrm{t}, \mathcal{E} 1_{t}$ is the error term (from equation 4 ) and $\varepsilon 2 t$ is the error term (from equation 5) respectively. $\alpha_{11}$ and $\alpha_{22}$ are $(n \times n)$ coefficient matrices.
Furthermore, the casual relationship between lending interest rate and credit to households is tested using a four-step procedure in reference to [20]. First, the unit root was conducted using the Augmented Dickey-Fuller (ADF) test, the Phillips and Peron (PP) test and the Kwiatkowski-Phillips-Schmidt-Shin (KPSS) test. These tests determine the order of integration for the two variables. The second step is doing a cointegration test in order to check on the presence of a long-run relationship among the variables. Cointegration test is conducted using the Johansen procedure. The third step is the Granger-causality procedure. This procedure tells if the variables predict one another [21]. The final fourth step will be the impulse response, which traces out the response of the dependent variable in the VAR model.

\subsection{Data and Sources}

This study uses monthly data, from 2000:01 to 2012:12. The two variables captured are lending interest rate and credit to households. The data series were obtained from the Bank of Namibia database.

\section{RESULTS AND DISCUSSION}

\subsection{Unit Root Tests}

The ADF, the PP and the KPSS tests are applied for unit root as stated earlier. The ADF and PP tests tend to under-reject the null hypothesis for unit root because of their limitation of lower power [4]. The KPSS is therefore, added as a confirmatory test. The results of unit root test in levels and first difference are presented in Table 1.

Results in Table 1 shows that the variables are non-stationary in level forms. However, after differencing once they became stationary. The variables are therefore integrated of order one (1). This is also confirmed by the KPSS test, and the results are presented in Table 2 below.

\subsection{Cointegration Test}

The results of the Johansen cointegration test, based on the Trace and Maximum Eigen Values tests are presented in Table 3. When the test statistics values are less than the critical values, then the null hypothesis of no cointegration cannot be rejected. In this case, it is shown that both the Trace and Maximum Eigen Values tests show that there is no cointegration equation. 
The meaning of these results is that there is no long-run relationship between lending interest rate and the volume of credit to households in Namibia. A relationship between lending rate and credit availability to households exist in the short run. The next step is to test the casual relationship between lending interest rate and credit to households.

\subsection{Granger Causality}

The casual results between lending interest rate and credit to households are presented in Table 4 below. When the probability is less than 0.05 , then the hypothesis of no causality is accepted.

In this case, the probability value of 0.019 is less than 0.05 . This means that the null hypothesis that credit to households does not granger causes lending interest rate is rejected.
Therefore, credit to households helps explain lending interest rate in Namibia however; lending interest rate does not help in explaining credit to households in Namibia. Changes in credit will induce a change in lending interest rate. There is a one-way relationship between lending interest rate and credit to households in Namibia, running from credit to household to lending interest rate. In this regard, credit expansion triggers monetary authorities to adjust interest rate in response to the inflationary effect that comes as a result of an expansion of credit in the Namibian economy, and not the other way round.

\subsection{Impulse Response Function}

The results of the impulse response function of lending interest rate to changes in credit to households are presented in Fig. 1 below:

\section{Response of LNLIR to Generalized One S.D. LNCH Innovation}

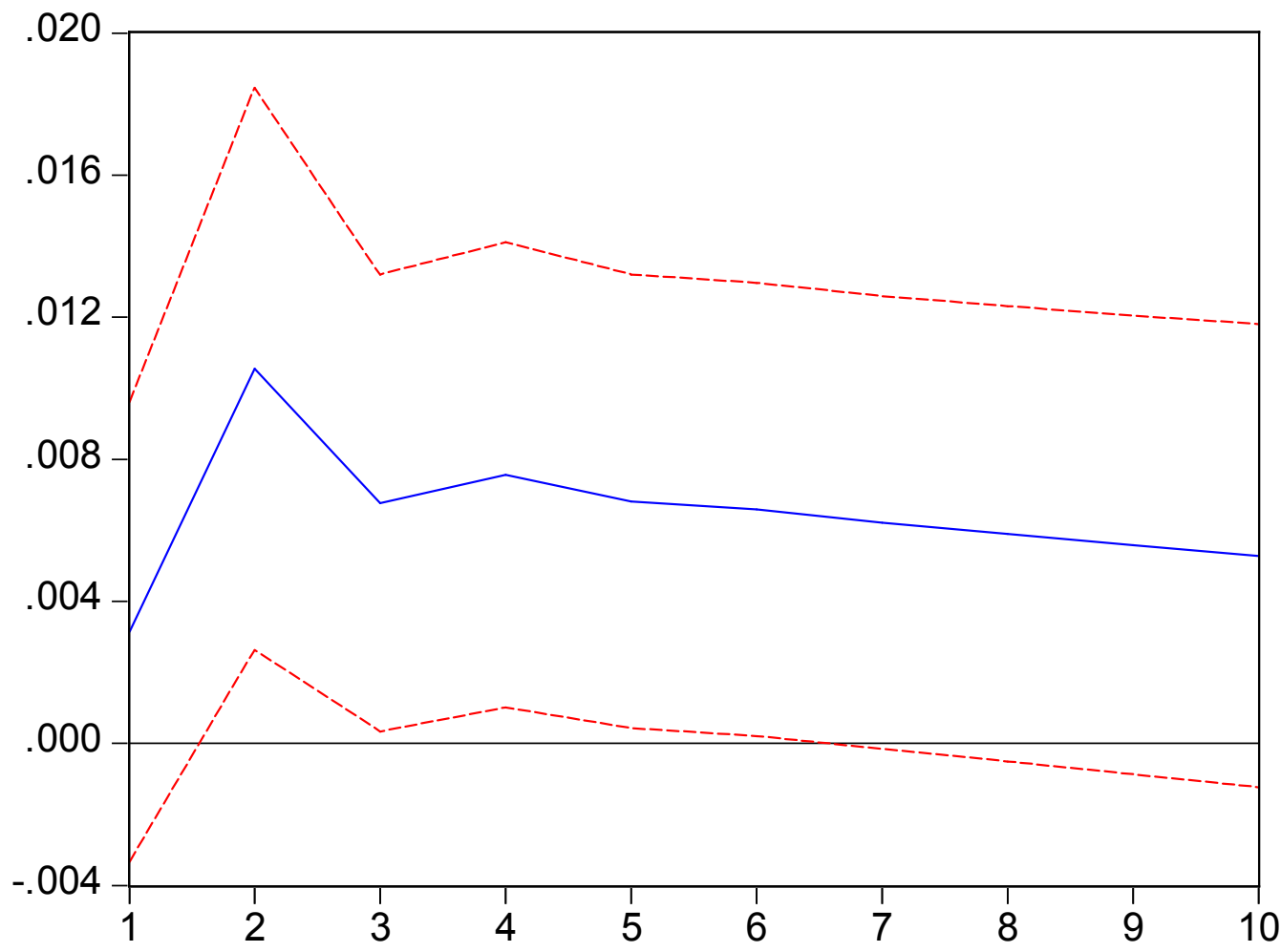

Fig. 1. Impulse Response Function of Lending Interest rate and Credit to Households Source: Authors' compilation using Eviews. 
Table 1. Unit root tests: ADF and PP in levels and first differences

\begin{tabular}{|c|c|c|c|c|c|c|}
\hline \multirow[t]{2}{*}{ Variable } & \multirow[t]{2}{*}{ Model specification } & \multicolumn{2}{|c|}{ ADF } & \multicolumn{2}{|r|}{ PP } & \multirow{2}{*}{$\begin{array}{l}\text { Order of } \\
\text { integration }\end{array}$} \\
\hline & & Levels & $\begin{array}{l}\text { First } \\
\text { difference }\end{array}$ & Levels & $\begin{array}{l}\text { First } \\
\text { difference }\end{array}$ & \\
\hline \multirow[t]{2}{*}{ InLIR } & Intercept & -1.573 & $-4.282^{* *}$ & -1.257 & $-16.315^{\star \star}$ & $\mathrm{I}(1)$ \\
\hline & Trend and Intercept & -2.715 & $-4.264^{* *}$ & -2.364 & $-16.275^{\star \star}$ & $\mathrm{I}(1)$ \\
\hline \multirow[t]{2}{*}{$\mathrm{InCH}$} & Intercept & -1.493 & $-8.331^{* *}$ & -1.450 & $-13.733^{\star *}$ & $\mathrm{I}(1)$ \\
\hline & Trend and Intercept & -1.082 & $-8.463^{\star *}$ & -1.751 & $-14.122^{\star *}$ & $\mathrm{I}(1)$ \\
\hline
\end{tabular}

Source: Authors' compilation and values obtained from Eviews. Notes: ** denotes a rejection of the null hypothesis at $5 \%$ level of confidence

Table 2. Unit root test: KPSS in levels and first differences

\begin{tabular}{lllll}
\hline Variable & Model specification & \multicolumn{2}{c}{ KPSS } & Order of \\
\cline { 3 - 5 } & & Levels & First difference & integration \\
\hline InLIR & Intercept & 1.019 & $0.059^{\star *}$ & $\mathrm{I}(1)$ \\
& Trend and Intercept & 0.113 & $0.058^{* *}$ & $\mathrm{I}(1)$ \\
$\mathrm{InCH}$ & Intercept & 1.515 & $0.214^{* *}$ & $\mathrm{I}(1)$ \\
& Trend and Intercept & 0.311 & $0.084^{* *}$ & $\mathrm{I}(1)$ \\
\hline
\end{tabular}

Source: Authors' compilation and values obtained from Eviews. Notes: ${ }^{* *}$ denotes a rejection of the null hypothesis at $5 \%$ level of confidence

Table 3. Johansen Cointegration test based on the trace and maximum eigen value tests

\begin{tabular}{lllll}
\hline & & Trace test & \multicolumn{2}{c}{ Maximum eigenvalue test } \\
\cline { 2 - 5 } $\begin{array}{l}\text { Hypothesized } \\
\text { No. of CE(s) }\end{array}$ & Trace & $\mathbf{0 . 0 5}$ & Maximum eigen- & $\mathbf{0 . 0 5}$ \\
\hline statistics & Critical value & value statistic & Critical value \\
At most 1 & 6.008561 & 15.49471 & 5.606777 & 14.26460 \\
\hline
\end{tabular}

Source: Authors' compilation using Eviews

Table 4. Pairwise Granger causality test for Lending Interest Rate and Credit to Households

\begin{tabular}{lc}
\hline Hypothesis & Probability \\
\hline LNCH does not Granger Cause & $0.01941^{* *}$ \\
LNLIR & \\
LNLIR does not Granger Cause & 0.24170 \\
LNCH & \\
\hline $\begin{array}{l}\text { Source: Authors' compilation using Eviews. Note: } \\
{ }^{* *} \text { denotes the rejection of the null hypothesis at } \\
\text { 5\% level of confidence }\end{array}$
\end{tabular}

An increase in credit availability to households leads to an increase in interest rate in this regards. It brings about a sharp increase in the first two years and then a decline after the second year. As the number of years increase, the lending interest rate will be decreasing monotonically. This simply shows that there exists a positive relationship between lending rate and credit volume to households in Namibia, which is confirmed by the one way causality which was determined earlier. The results are in line with the theory that an increase in credit availability brings about an increase in lending rate. The shock in credit volume is transitory for about nine months and become permanent thereafter.

\section{CONCLUSION}

This study looked at the casual relationship between lending interest rate and credit volume to households in Namibia. The unit root, cointegration and Granger-causality techniques were adopted, using monthly data between 
2000:01 and 2012:12. The results revealed that the two variables were stationary and there was no long-run but only a short run relationship among them. Credit availability was found to explain lending interest rate in Namibia while lending rate was unable to explain credit availability. There was no clear conclusion on the response of credit to lending interest rate because there was no causality from lending rate. However, the positive reaction of lending interest rate to credit, as well as the one-way casual impact, coming from credit means that the authorities in the Namibian economy should consider the effect on credit availability when adjusting monetary policy instruments such as the lending interest rate. When the economy is faced by credit expansion, to avoid a rapid increase in inflation, the authority responds by tightening lending interest rate thereby reducing the volume of money circulation in the economy. Such a move can affect household consumption.

\section{COMPETING INTERESTS}

Authors have declared that no competing interests exist.

\section{REFERENCES}

1. Ersado L, Alwang J, Alderman H. Changes in consumption and saving behavior before and after economic shocks: Evidence from Zimbabwe. Paper Presented at International Food and Agribusiness Management Association Conference, Chicago, USA; 2000.

2. Hansen HJ. The impact of interest rates on private consumption in Germany. Deutche Bundesbank working papers. 1996;3:1-76.

3. Nakagawa S, Oshima K. Does a decrease in the real interest rate actually stimulate personal consumption? An Empirical study. Bank of Japan Working Papers. 2000;00-2:1-8.

4. Sheefeni JPS. The relationship between deposit and lending rates in Namibia. Asian Journal of Business and Management. 2013;1(4):179-184.

5. Nguyen CV, Islam AM, Ali MM. Bangladeshi lending-deposit rate spread: an econometric analysis. Global Economy and Finance Journal. 2010;3(2):238-246.
6. Burgstaller J. Interest rate pass-through estimates from autoregressive model. Working Papers No 0510; 2005.

7. Modigliani F. Fluctuations in the savingsincome ratio: A problem in economic forecasting. Studies in income and wealth. National Bureau of Economic Research. 1949;369-444.

8. Trumbull G. Regularly for legitimacy: consumer credit access in France and America. Harvard Business School Working Papers; 2010.

9. Modigliani F. Brumberg R. Utility analysis and the consumption Function: An interpretation of cross-section data. In KuriharaK. (Ed.). Post-keynesian economics. Rutgers University Press; 1954.

10. Parker J. 16 Theories of consumption and savings. Economics 314 course book. Available:www.academic.reed.edu/econom ics/parker/.2010

11. Gul E, Ekinci A. The casual relationship between Nominal interest rates and inflation: The case of Turkey. Scientific Journal of Administrative Development. 2006;4:54-69.

12. Holmes $\mathrm{C}$. The Impact of credit constraints on consumption. JEL Classification. 2010;3-20.

13. Flaving $M$. Excess sensitivity of consumption to current income: Liquidity constraints or myopia? Canadian Journal of Political Economy. 1985;18:117-136.

14. Vaidyanathan G. Consumption, liquidity constraint and economic development. Journal of Macroeconomic. 1993;15:591610.

15. Wilcox JA. Liquidity constraints on consumption: The real effects of lending policies. Federal Bank of San Francisco Working Papers; 1989.

16. Byrd K, Ross LW, Glackin CEW. A preliminary casual analysis of small business access to credit during economic expansion and contraction. Journal of Applied Finance and Banking. 2013;3(5): 77-84.

17. Cappiello L, Kaderaja A, Sorensen CK, Protopapa M. Do bank loans and credit standards have an effect on output? A panel approach for the Euro area. European Central Bank working Papers; 2009. 
18. Dey MK, Flaherty S. Stock exchange liquidity, bank credit, and economic growth. Paper presented at the max fry conference on France and development. The business school University, Birmingham; 2005.

19. Kaplin A, Levy A, Qu S, Wang D, Wang Y, Zhang J. The relationship between default risk and interest rates: An empirical study. Moody's Analysis Working Papers; 2009.
20. Chidothi D, Sheefeni JPS. The relationship between inflation and stock prices in Zambia. Asian Journal of Business and Management. 2013;1(4):185-192.

21. Stock JH, Watson MW. Vector autoregressions. Journal of Economic Perspective. 2001;15(4):101-115.

(c) 2015 Kalumbu and Nyambe; This is an Open Access article distributed under the terms of the Creative Commons Attribution License (http://creativecommons.org/licenses/by/4.0), which permits unrestricted use, distribution, and reproduction in any medium, provided the original work is properly cited.

Peer-review history:

The peer review history for this paper can be accessed here: http://www.sciencedomain.org/review-history.php?iid=981\&id=20\&aid=8993 